\title{
Mealiness of 'Forelle' Pears - Quo Vadis?
}

E.M. Crouch \& M. Huysamer

Department of Horticultural Science, University of Stellenbosch, P. Bag X1, Matieland, 7602, South Africa

D. M. Holcroft

DOLE Fresh Vegetables, P.O. Box 1759, Salinas, CA 93902, USA

Keywords: Pyrus communis, ethylene, 1-aminocyclopropane-1-carboxylic acid, mealiness

\begin{abstract}
'Forelle' (Pyrus communis), a late season blushed pear cultivar grown in South Africa, requires a minimum of 12 -weeks cold storage $\left(-0.5^{\circ} \mathrm{C}\right)$ to ripen evenly. Mealiness, a dry texture disorder, may develop at this time. In contrast to other pear cultivars, longer cold storage periods result in less mealiness. This could be related to insufficient total ACC build up and ethylene production, during the first 12 weeks of cold storage, for juicy texture development, during ripening. 'Forelle' pears were stored for 3 weeks at $-0.5^{\circ} \mathrm{C}$, treated with ethylene $\left(100 \mu \mathrm{L} \mathrm{L} \mathrm{L}^{-\mathrm{P}}, 24 \mathrm{~h}, 20^{\circ} \mathrm{C}\right)$, stored at $20^{\circ} \mathrm{C}$ for 2 days and thereafter 3 weeks at $-0.5^{\circ} \mathrm{C}$. Ethylene treatment led to an increase in mealiness after this period. However there were no differences in treated and control fruit following further ripening at $15^{\circ} \mathrm{C}$ for 7 days. Mealiness could not be linked to insufficient ethylene during shorter storage periods. Harvest maturity, a factor known to influence mealiness, was tested by harvesting fruit 2 weeks prior to commercial harvest, during commercial harvest, and 2 and 4 weeks after commercial harvest. Mealiness occurred at all harvest dates after 6 weeks at $-0.5^{\circ} \mathrm{C}$ and 7 days at $15^{\circ} \mathrm{C}$. Storage temperature was also tested as another factor influencing mealiness. Fruit were stored at $-0.5^{\circ} \mathrm{C}, 4^{\circ} \mathrm{C}$ and $7.5^{\circ} \mathrm{C}$ for 6 weeks and ripened for 7 days at $15^{\circ} \mathrm{C}$. Fruit stored at $4^{\circ} \mathrm{C}$ and $7.5^{\circ} \mathrm{C}$ ripened with 0 and $8 \%$ mealiness, respectively, in contrast to $70 \%$ in control fruit. Results could, however, not be confirmed in 2002 and 2003 as all treatments exhibited low mealiness levels $(<4 \%)$. As high temperatures prior to harvest may influence mealiness, overhead evaporative cooling was applied during 2003 from early fruit development or from 2 weeks prior to harvest. Little to no mealiness developed in all treatments making it difficult to conclude if cooling prior to harvest affects mealiness.
\end{abstract}

\section{INTRODUCTION}

Texture is a critical feature of pear quality and depends on many factors i.e. time of harvesting, conditions and duration of storage and post-storage ripening as well as climatic factors which are still poorly documented (Zerbini, 2002). 'Forelle' is a winter pear with a mandatory 12 -week cold storage period $\left(-0.5^{\circ} \mathrm{C}\right)$ to ensure even ripening and minimise mealiness (De Vries and Hurndall, 1993). In contrast to 'd' Anjou', 'Marguerite Marillat' and 'La France' pears, which do not regain their juicy texture after prolonged storage at low temperatures (Chen et al., 1983; Murayama et al., 2002), mealiness of 'Forelle' pears decreases with time in cold storage $\left(-0.5^{\circ} \mathrm{C}\right)$ (Martin et al., 2003).

Insufficient cold storage prior to ripening can cause pears to develop a dry texture (Mitchell, 1990). Low temperatures stimulate ACC-synthase and ACC-oxidase (ACO) necessary for an ethylene climacteric and normal ripening to occur (Lelièvre et al., 1997).

Exogenous ethylene treatment can compensate for an incomplete cold requirement to initiate ripening (Chen and Mellenthin, 1981) and may improve textural and flavour qualities in pears where the cold requirement has not been satisfied (Mitchell, 1990). However, inactivation of $A C O$ and suppression of ethylene production in nectarines by chilling temperatures was recently shown (Zhou et al., 2000).

Pear fruit harvested immature do not reach a climacteric and do not ripen, or ripen unevenly (Ben-Arie and Sonego, 1979). Pears harvested too late often develop a mealy texture (Mellenthin and Wang, 1976). 
Hansen (1961) associated mealiness with growing seasons with high total heat units. Mellenthin and Wang (1976) also reported that fruit grown in high daily-hour temperatures six weeks prior to harvest, failed to ripen uniformly and were susceptible to certain physiological disorders, including mealiness. High temperatures prior to harvest in the Western Cape region of South Africa necessitates an investigation into the role it plays in mealiness development.

Texture development is a complex feature during ripening, since it is influenced by so many factors. This paper quantifies some of these influential factors to enable a better understanding of mealiness development in 'Forelle' pears.

\section{MATERIAL AND METHODS}

\section{Exogenous Ethylene Trial}

'Forelle' pears were harvested (Western Cape, South Africa) (2001) with an average flesh firmness of $6.0 \mathrm{~kg}$. Forty fruit were sampled for maturity assessment at harvest. Fruit were stored for 3 weeks at $-0.5^{\circ} \mathrm{C}$ prior to ethylene treatment. Samples were drawn after 3 weeks of storage at $-0.5^{\circ} \mathrm{C}$ and allowed to ripen for 7 days at $15^{\circ} \mathrm{C}$, to determine mealiness occurrence. After 3 weeks of storage half the remaining fruit were treated with $100 \mu \mathrm{L} \mathrm{L}^{-1}$ ethylene in air, at $20^{\circ} \mathrm{C}$ for 24 hours. After ethylene treatment, fruit was held at $20^{\circ} \mathrm{C}$ in air for a further 48 hours. Control fruit were treated in air. Samples were evaluated for maturity after the 72 hour treatment period. Thereafter all remaining fruit were stored for a further 3 weeks and then evaluated immediately and again after 7 days at $15^{\circ} \mathrm{C}$. Each sampling date consisted of 5 replicates of 8 fruit per replicate. A further 8 fruit were used to determine ethylene production (static system). Fruit were placed in $5 \mathrm{~L}$ containers at $20^{\circ} \mathrm{C}$ and samples were taken after $1 \mathrm{~h}$. Ethylene was measured with a flame ionization gas chromatograph (Varian, Model 3300, USA).

Flesh firmness was measured using a penetrometer (Southtrade, Italy) fitted with an $8 \mathrm{~mm}$ probe. Mealiness was determined by cutting fruit equatorially. Fruit with expressed juice on the equatorial surface after compaction were classified as non-mealy, whereas those with a dry texture were considered mealy. Extractable juice $(\mathrm{EJ})\left(\mathrm{mL} \mathrm{cm}^{-3}\right)$ was measured with a Chylofel (COPA-Technologie S.A. France). The Chylofel was used on opposite cheeks, and juice of the 8 fruit in each of the 5 replicates was pooled.

Data were analysed using the GLM (General Linear Models) procedure running the fisher's t-test in the SAS (Statistical Analysis System) programme (SAS Institute Inc., 1990).

\section{Harvest Maturity Trial}

'Forelle' pears were harvested in 2001 (Warm Bokkeveld, Western Cape Province), 2 weeks prior to commercial harvest (H1), at commercial harvest (H2), and 2 and 4 weeks after commercial harvest ( $\mathrm{H} 3$ and $\mathrm{H} 4$, respectively). Fruit were analysed at harvest, after 6 weeks of storage at $-0.5^{\circ} \mathrm{C}$ (maximum mealiness incidence in 2000 season, data not shown), and again after ripening at $15^{\circ} \mathrm{C}$ for 7 days. Flesh firmness, mealiness and ethylene production were measured and data analysis was conducted as previously described.

\section{Storage Temperature Trial}

'Forelle' pears were harvested in the Theewaterskloof area (Western Cape, South Africa) at a commercial maturity (2001) with an average flesh firmness of $6.0 \mathrm{~kg}$ and total soluble solids (TSS) of $13.7 \%$. Ground colour chart index was 2.6 (where $0.5=$ dark green, 5 = deep yellow).

Forty-eight fruit were sampled for initial maturity assessment at harvest. The remainder of the fruit was stored for 3 and 6 weeks at $-0.5^{\circ} \mathrm{C}, 4^{\circ} \mathrm{C}$ and $7.5^{\circ} \mathrm{C}$. Flesh firmness, extractable juice and mealiness were measured as described in Martin et al. (2003). 1-Aminocyclopropane-1-carboxylic acid (ACC) sample preparation was done on 
peeled fruit disks according to Kasai et al. (1996) and analysed according to Lizada and Yang (1979). Ethylene production was measured as previously described.

Data were analysed as described in previous trial.

\section{Overhead Cooling Trial}

This trial was conducted at the Welgevallen experimental farm (Stellenbosch, South Africa) on 'Forelle' pears. Trees were grafted on Quince A rootstock and planted in 1998 at $4 \mathrm{~m}$ x $2 \mathrm{~m}$ spacing. Micro sprinklers (DAN 2001 jets) with a $28 \mathrm{~L} \mathrm{~h}^{-1}$ discharge were installed on $4.5 \mathrm{~m}$ high poles $(8 \mathrm{~m}$ apart) with jets every $2.5 \mathrm{~m}$ along a suspended pipe. Activation temperatures were set at $30^{\circ} \mathrm{C}$ between $08 \mathrm{~h} 00$ and $18 \mathrm{~h} 00$ and $22^{\circ} \mathrm{C}$ between $18 \mathrm{~h} 00$ and $21 \mathrm{~h} 00$. Pulsing cycles of 5 minutes on, 15 minutes off were used. Normal undertree irrigation was given to all treatments.

Overhead cooling was started either on 3 December 2002, (Early Cooling; EC), or on 7 February 2003 (Late Cooling; L), whereas control (C) trees did not receive any overhead cooling. Treatments were randomly assigned to two blocks and data were analysed using the GLM (General Linear Models) procedure in the SAS (Statistical Analysis System) programme (SAS Institute Inc., 1990).

'Forelle' fruit were harvested on 18 February 2003, with an average flesh firmness of $6.9 \mathrm{~kg}$ and TSS of $15 \%$. Fruit were evaluated immediately after harvest and again after 7 days of ripening at $15^{\circ} \mathrm{C}$. The remainder of the fruit was stored at $-0.5^{\circ} \mathrm{C}$ directly after harvest for 12 weeks whereafter fruit was ripened for 0,7 or 11 days at $15^{\circ} \mathrm{C}$ and evaluated at these times. Ground colour changes were measured as hue angle $\left(h^{\circ}\right)$ using a colorimeter (Nippon Denshoku, Model HR-3000, Japan) and ground colour chart index. Flesh firmness and percentage mealiness were measured as described previously.

\section{RESULTS}

\section{Exogenous Ethylene Trial}

Ethylene treatment led to a significant decrease in fruit firmness (Fig. 1A) and an increase in mealiness (Fig. 1B). However, there were no differences between treated and control fruit following ripening at $15^{\circ} \mathrm{C}$ for 7 days after the remaining storage period at $-0.5^{\circ} \mathrm{C}$. Extractable juice of fruit measured directly after ethylene treatment was lower $\left(0.84 \mathrm{~mL} \mathrm{~cm}^{-3}\right)$ than in control fruit at the same time $\left(6.72 \mathrm{~mL} \mathrm{~cm}^{-3}\right)$, but both treatments had no juice at the end of the additional 3 week storage period at $-0.5^{\circ} \mathrm{C}$ followed by 7 days at $15^{\circ} \mathrm{C}$.

\section{Harvest Maturity Trial}

Flesh firmness was lowest for fruit harvested 2 weeks prior to commercial harvest $(6.0 \mathrm{~kg})$ (Fig. 2A). Flesh firmness for fruit harvested on the other harvest dates was similar at $\pm 6.3 \mathrm{~kg}$. Only the fruit harvested on $\mathrm{H} 1$ and $\mathrm{H} 4$ ripened to an edible firmness after 6 weeks of storage at $-0.5^{\circ} \mathrm{C}$ followed by 7 days at $15^{\circ} \mathrm{C}$. Fruit harvested during commercial harvest had only a $0.5 \mathrm{~kg}$ drop in firmness even after 7 days of ripening at $15^{\circ} \mathrm{C}$, due to contamination with 1-methylcyclopropene (1-MCP).

Mealiness was unacceptably high for fruit from H1, H3 and H4 (Fig. 2B). Fruit from the commercial harvest $(\mathrm{H} 2)$ had no mealiness since fruit failed to soften due to contamination with 1-MCP.

No ethylene production was detected directly after harvest for fruit from all harvest dates. After 6 weeks at $-0.5^{\circ} \mathrm{C}$, a small concentration of ethylene was measured for fruit harvested at $\mathrm{H} 1$. Ethylene production was even less for $\mathrm{H} 3$ and $\mathrm{H} 4$ $\left( \pm 1.6 \mu \mathrm{L} \mathrm{kg}^{1} \mathrm{~h}^{-1}\right)$ than $\mathrm{H} 1\left(11.1 \mu \mathrm{L} \mathrm{kg}^{-1} \mathrm{~h}^{-1}\right)$. $\mathrm{H} 1$ fruit that were stored for 6 weeks at $-0.5^{\circ} \mathrm{C}$ and 7 days at $15^{\circ} \mathrm{C}$ had the highest ethylene production $\left(37 \mu \mathrm{L} \mathrm{kg}^{-1} \mathrm{~h}^{-1}\right)$, but fruit harvested at $\mathrm{H} 3$ and $\mathrm{H} 4$ also produced ethylene $\left(25.6\right.$ and $23.1 \mu \mathrm{L} \mathrm{kg}^{-1} \mathrm{~h}^{-1}$, respectively). Only a trace amount of ethylene could be detected from the 1-MCP' contaminated fruit at commercial harvest maturity, after ripening $\left(1.7 \mu \mathrm{L} \mathrm{kg}^{-1} \mathrm{~h}^{-1}\right)$. 


\section{Storage Temperature Trial}

The loss in firmness and mealiness development for the temperature treatments were previously described (Martin et al., 2003). Extractable juice $\left(\mathrm{mL} \mathrm{cm}^{-3}\right)$ was lowest after 6 weeks at $-0.5^{\circ} \mathrm{C}$ followed by 7 days at $15^{\circ} \mathrm{C}$, and decreased from $3.5 \mathrm{~mL} \mathrm{~cm}^{-3}$ at the beginning of storage to $0.6 \mathrm{~mL} \cdot \mathrm{cm}^{-3}$ after 7 days at $15^{\circ} \mathrm{C}$. A similar decrease was noted for fruit stored for 6 weeks at $7.5^{\circ} \mathrm{C}$, which reached a minimum of $0.5 \mathrm{~mL} \mathrm{~cm}^{-3}$ at the end of storage followed by 7 days at $15^{\circ} \mathrm{C}$. After 6 weeks of storage at $4^{\circ} \mathrm{C}$, and ripening for 7 days at $15^{\circ} \mathrm{C}$ fruit exhibited about $133 \%$ more extractable juice than fruit stored at $-0.5^{\circ} \mathrm{C}$ and $7.5^{\circ} \mathrm{C}$, and examined at the same time.

Ethylene production rate was highest for fruit stored at $7.5^{\circ} \mathrm{C}$ for 6 weeks (Fig. 3A). Only after 6 weeks of storage and 7 days at $15^{\circ} \mathrm{C}$ did the ethylene production rate of fruit stored at $4^{\circ} \mathrm{C}$ increase to $30.9 \mu \mathrm{L} \mathrm{kg}^{-1} \mathrm{~h}^{-1}$, which was significantly higher than for fruit stored at $-0.5^{\circ} \mathrm{C}$, and significantly lower than for fruit stored at $7.5^{\circ} \mathrm{C}$. Even after ripening, fruit stored at $4^{\circ} \mathrm{C}$ and $-0.5^{\circ} \mathrm{C}$, did not reach the high levels in ethylene production rate that were measured following storage at $7.5^{\circ} \mathrm{C}$.

The change in total ACC concentration $\left(\mathrm{nmol} \cdot \mathrm{g}^{-1}\right)$ was significantly different between storage temperature treatment. Fruit stored at $7.5^{\circ} \mathrm{C}$ and $4^{\circ} \mathrm{C}$ for 6 weeks had a higher total ACC content than fruit stored at $-0.5^{\circ} \mathrm{C}$ (Fig. 3B).

\section{Evaporative Cooling Trial}

Harvested fruit had no significant differences between treatments in ground colour $(+/-2.5)$, TSS $(+/-15 \%)$ and tissue firmness $(6.8-7.0 \mathrm{~kg})$. Differences in maturity indices between fruit from early evaporative cooling (EC), late evaporative cooling (L) and no evaporative cooling $(\mathrm{C})$ were non-significant during ripening and no development of mealiness was noted.

\section{DISCUSSION}

Ethylene treated and untreated 'Forelle' pears were mealy. In the ethylene treated fruit, mealiness was observed 3 weeks earlier and was more pronounced than in the untreated control fruit. These fruit, however, were of an advanced maturity, which made them more suitable for mealiness assessment than control fruit. Even though exogenous ethylene treatment could compensate for an incomplete cold requirement to initiate ripening, i.e. loss in firmness, this has not been found to improve textural qualities specifically mealiness in this pear cultivar. Even though mealiness of 'Forelle' pears decreases with time in cold storage $\left(-0.5^{\circ} \mathrm{C}\right)$ and it is known that prolonged storage could satisfy the requirement for the threshold ACC (Martin et al., 2003), it is known that the ripening process of pome fruit involves many individual reactions which are not necessarily related to each other but occur more or less in parallel (and in time) relative to the climacteric (Frenkel et al., 1968). This seems to be the case in 'Forelle'. The insufficient build up of ethylene or ACC does not seem to be related to mealiness development during early cold storage.

Fruit harvested at both the start and end of the picking window were of a more advanced maturity after cold storage and ripening at $15^{\circ} \mathrm{C}$, than the fruit picked on the other harvest dates. Fruit seldom soften on the tree, although exposure to cool temperatures can cause premature ripening due to an accumulation of ACC causing ethylene production (Agar et al., 1999). Climatic conditions before each harvest date play an important role in determining fruit quality. Mellenthin and Stebbins (1980) reported that premature ripening of 'Bartlett' pears occurred 30 days prior to harvest when there were two consecutive cold nights at a temperature of $\pm 7.2^{\circ} \mathrm{C}$ with daytime temperatures at $\pm 21.1^{\circ} \mathrm{C}$. This might be the case for the first harvest date, which was $0.7 \mathrm{~kg}$ softer at harvest, had a higher total ACC concentration and higher ethylene production rate than later harvested fruit. This indicates that the fruit harvested 2 weeks before commercial harvest were already mature (i.e. able to ripen). Fruit were selected and marked prior to the first harvest to exclude the effects of protracted blossoming and position on the tree. 
Murayama et al. (1998) found that 'Marguerite Marilatt' and 'La France' pears left on the tree for 28 days after optimum harvest had one third less water soluble pectin, which is associated with mealiness, than fruit harvested at optimum maturity and ripened off the tree. Fruit harvested 2 weeks after commercial harvest (H3) were $50 \%$ mealy after 6 weeks of storage at $-0.5^{\circ} \mathrm{C}$ and 7 days at $15^{\circ} \mathrm{C}$, which was lower than fruit harvested in $\mathrm{H} 1$ and $\mathrm{H} 4$ (100\% and $73 \%$, respectively). However, firmness values were higher and ground colour did not reach the same deep yellow compared to the first and last harvest date. Since these fruit were firmer, and firmness affects mealiness, this may explain the lower incidence of mealiness. Data in the 2003 season showed a similar pattern (data not shown). It would appear that, in contrast to 'Marguerite Marilatt' and 'La France', factor(s) other than harvest maturity play a more important role in the initiation of mealiness in 'Forelle' pears.

Storage temperature influenced ripening and thus all maturity indices of 'Forelle' pears. Fruit stored for 6 weeks at $-0.5^{\circ} \mathrm{C}$ were only $0.5 \mathrm{~kg}$ firmer than fruit stored at $4^{\circ} \mathrm{C}$. Marked losses in firmness occurred only after transfer to $15^{\circ} \mathrm{C}$, whereas fruit stored at $7.5^{\circ} \mathrm{C}$ softened considerably after only 3 weeks of storage followed by 7 days at $15^{\circ} \mathrm{C}$. Fruit stored at the higher temperatures had little to no mealiness, whereas fruit stored at $-0.5^{\circ} \mathrm{C}$ were $70 \%$ mealy. Fruit stored at $-0.5^{\circ} \mathrm{C}$ did not have the ability to produce high levels of ethylene. A similar trend was observed by Sfakiotakis and Dilley (1974), who reported that $5^{\circ} \mathrm{C}$ and $7.5^{\circ} \mathrm{C}$ for seven days in preclimacteric 'Bosc' pears were more effective than $0^{\circ} \mathrm{C}$ in developing competency to produce ethylene. The higher storage temperatures $\left(4^{\circ} \mathrm{C}\right.$ and $\left.7.5^{\circ} \mathrm{C}\right)$ promoted ACC accumulation and conversion of ACC to ethylene. Unlike in nectarines where woolliness was alleviated by the application of exogenous ethylene (Dong et al., 2001), exogenous ethylene promoted ripening in 'Forelle' and as a consequence, mealiness could be observed earlier than in untreated fruit. Mealiness was thus induced during storage, before ethylene treatment, and the disorder is not reversed by exogenous ethylene. It appears that ACC accumulation at higher temperatures is thus not related to mealiness, but to another temperature related factor. No mealiness development in 2002 and 2003 seasons necessitates repetition of this trial to confirm results.

Hansen (1961) associated a 53-70\% incidence of mealiness to growing seasons with high total heat units and Mellenthin and Wang (1976) reported that fruit grown in high daily-hour temperatures six weeks prior to harvest, failed to ripen uniformly and were susceptible to mealiness. No mealiness development in the evaporative cooling trial with a number of days over $30^{\circ} \mathrm{C}$ leads to the conclusion that $30^{\circ} \mathrm{C}$ might not have been the threshold temperature necessary for the induction of mealiness development. A higher threshold temperature or threshold number of hours at this temperature might play a role.

Existing longer term climatic research and correlations to mealiness should make these influences more clear, and give us a better understanding of pre-harvest temperatures on texture development of pears.

\section{ACKNOWLEDGEMENTS} Foundation.

Research funded by the Deciduous Fruit Producers Trust and National Research

\section{Literature Cited}

Agar, I.T., Biasi, W.V. and Mitcham, E.J. 1999. Exogenous ethylene accelerates ripening responses in Bartlett pears regardless of maturity or growing region. Postharvest. Biol. Technol. 17: 67-78.

Ben-Arie, R. and Sonego, L. 1979. Changes in the pectic substance of ripening pears. J. Amer. Soc. Hort. Sci. 104: 500-505.

Chen, P.M. and Mellenthin, W.M. 1981. Effects of harvest date on ripening capacity and postharvest life of 'd'Anjou' pears. J. Amer. Soc. Hort. Sci. 106: 38-42.

Chen, P.M., Mellenthin, W.M. and Borgic, D.M. 1983. Changes in ripening behavior of 'd'Anjou' pears (Pyrus communis L.) after cold storage. Scientia Hort. 21: 137-146. 
Dong, L., Zhou, H., Sonego, L., Lers, A. and Lurie, S. 2001. Ethylene involvement in cold storage disorder of 'Flavortop' nectarine. Postharvest Biol. Technol. 23: 105-115.

De Vries, P.J. and Hurndall, R.F. 1993. Maturity parameters and storage regimes to obtain 'Forelle' pears of an acceptable eating quality. Unifruco Research report 1993: 95-99.

Frenkel, C., Klein, I. and Dilley, D.R. 1968. Protein synthesis during ripening of pome fruits. Plant Physiol. 43: 1146-1153.

Hansen, E. 1961. Climate in relation to postharvest physiological disorders of apples and pears. Proc. Oregon Hort. Soc. 53: 54-58. (Cited by Raese, 1989).

Kasai, Y., Kato, M. and Hyodo, H. 1996. Ethylene biosynthesis and its involvement in senescence of broccoli florets. J. Japan. Soc. Hort. Sci. 65: 185-191.

Lelièvre, J., Latché, A., Jones, B., Bouzayen, M. and Pech, J. 1997. Ethylene and fruit ripening. Physiol. Plant. 101: 727-739.

Lizada, M.C.C. and Yang, S.F. 1979. A simple and sensitive assay for 1aminocyclopropane-1 carboxylic acid. Anal. Biochem. 100: 140-145.

Martin, E.M, Crouch, I.J. and Holcroft, D.M. 2003. Ripening and mealiness of 'Forelle' pears. Acta Hort. 600: 449 -452.

Mellenthin, W.M. and Wang, C.Y. 1976. Preharvest temperatures in relation to postharvest quality of 'd'Anjou' pears. J. Amer. Soc. Hort. Sci. 101: 302-305.

Mellenthin, W.M. and Stebbins, R.L. 1980. Control of premature ripening of 'Bartlett' pears. Technical bulletin, No. FS 241. Extension Service, Oregon State University, Corvallis.

Mitchell, F.G. 1990. Postharvest biology and technology of European pears. In: Pear Production Manual. Department of Pomology, University of California Davis, Davis, CA.

Murayama, H., Takahashi, T., Honda, R. and Fukushima, T. 1998. Cell wall changes in pear fruit softening on and off the tree. Postharvest Biol. Technol. 14: 143-149.

Murayama, H., Katsumata, T., Horiuchi, O. and Fukushima, T. 2002. Relationship between fruit softening and cell wall polysaccharides in pears after different storage periods. Postharvest Biol. Technol. 26: 15-21.

Raese, J.T. 1989. Physiological disorders and maladies of pear fruit. Hort. Rev. 11: $357-$ 411.

Sfakiotakis, E.M. and Dilley, D.R. 1974. Induction of ethylene production in 'Bosc' pears by postharvest cold stress. HortScience 9: 336-338.

Zhou, H.W., Dong, L., Ben-Arie, R. and Lurie, S. 2000. The role of ethylene in the prevention of chilling injury in nectarines. J. Plant Physiol. 158: 55-61.

Zerbini, P.E. 2002. The quality of pear fruit. Acta Hort. 596: 805-810. 


\section{Figures}
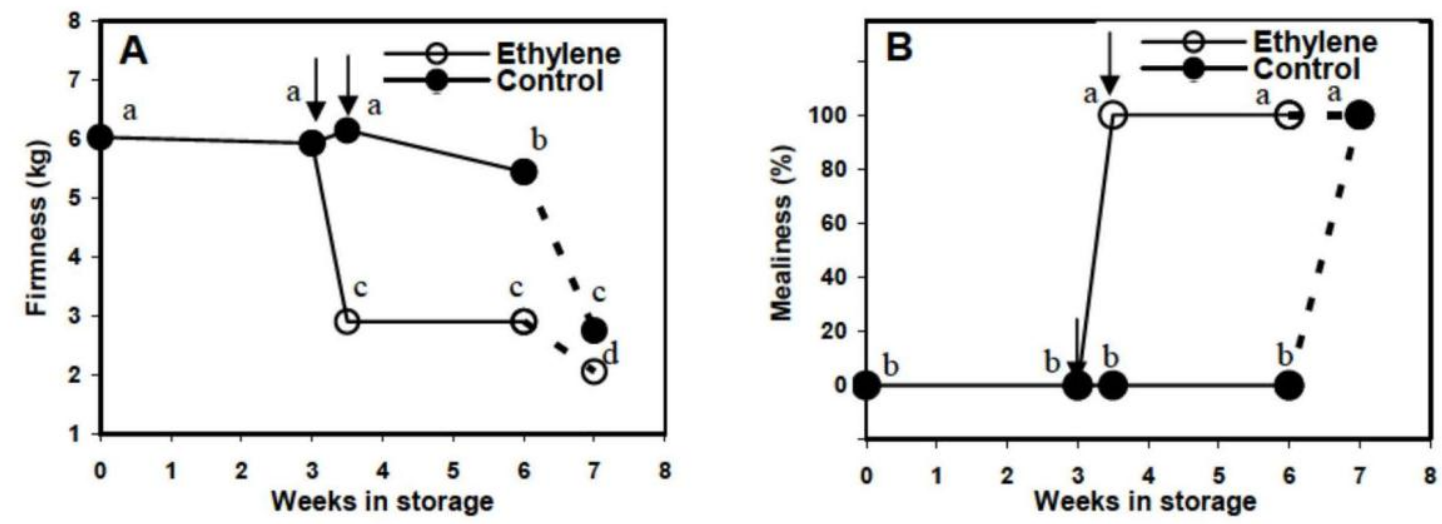

Fig. 1. Firmness (A) and mealiness (B) of 'Forelle' pears treated with ethylene $(100 \mu \mathrm{L}$ $\left.\mathrm{L}^{-1}\right)(\downarrow)$ for $24 \mathrm{~h}$, followed by $48 \mathrm{~h}$ at $20^{\circ} \mathrm{C}$ in air before being returned to $-0.5^{\circ} \mathrm{C}$ for a further 3 weeks $(\downarrow)$. Control fruit were stored at same temperatures but with an air treatment instead of ethylene (Dashed lines indicate ripening at $\left.15^{\circ} \mathrm{C}\right)(\mathrm{A}$, $\mathrm{LSD}_{5 \%}=0.21 ; \mathrm{B}$, logit transformed data; small letters indicate significant differences).
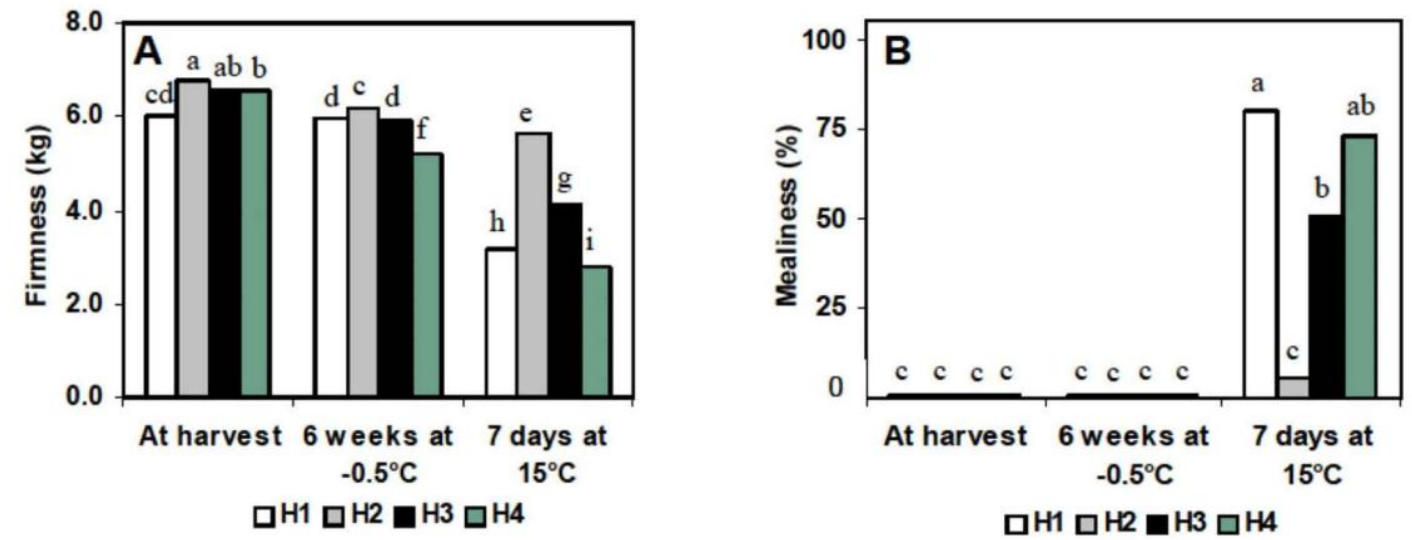

Fig. 2. Firmness (A) and mealiness (B) of 'Forelle' pears harvested 2 weeks prior to commercial harvest $(\mathrm{H} 1)$, at commercial harvest $(\mathrm{H} 2), 2$ weeks after commercial harvest $(\mathrm{H} 3)$ and 4 weeks after commercial harvest $(\mathrm{H} 4) .\left(\mathrm{A}, \mathrm{LSD}_{5 \%}=0.38 ; \mathrm{B}\right.$, Logit transformed data; small letters indicate significant differences). 

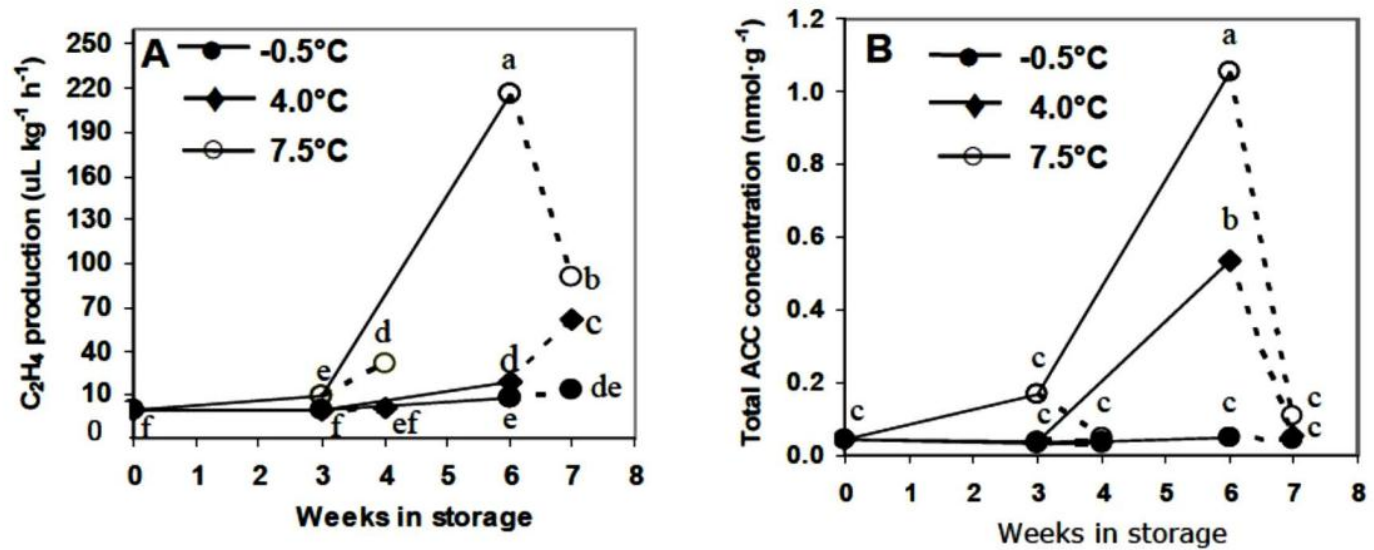

Fig. 3. Ethylene production rate $\left(\mu \mathrm{L} \mathrm{kg}^{-1} \mathrm{~h}^{-1}\right)$ (A) and total ACC concentration (nmol g-1) (B), of 'Forelle' pears stored at $-0.5^{\circ} \mathrm{C}, 4^{\circ} \mathrm{C}$ and $7.5^{\circ} \mathrm{C}$ (dashed lines indicating days at $\left.15^{\circ} \mathrm{C}\right) .\left(\mathrm{A}, \mathrm{LSD}_{5 \%}=13.64 ; \mathrm{B}, \mathrm{LSD}_{5 \%}=0.33\right.$; small letters indicate significant differences). 